\title{
Regulated free banking in Switzerland (1881-1907)
}

\author{
Nils Herger ${ }^{*}$ (1)
}

\begin{abstract}
The free-banking history of Switzerland is subdivided into periods with unfettered competition (1826-1881), and strict banknote regulation (1881-1907). This paper suggests that the Federal Banknote Act of 1881 was introduced to remedy the fragmentation of the unfettered-competition period, during which private note-issuing banks were unable to issue standardised paper money. Although the corresponding minimum-reserve and mutual-acceptance rules led to a standardisation, they created new problems. For example, these regulatory interventions reduced the flexibility (or "elasticity") of the paper-money supply. It turned out that a central note-issuing bank is needed to supply adequate amounts of standardised banknotes.
\end{abstract}

Keywords: Central bank, Free banking, Note-issuing bank, Switzerland

JEL Classification: E42, N14, N23

\section{Introduction}

Free banking refers to a money system, in which paper money is issued in a competitive manner by private noteissuing banks, rather than through a government monopoly with a central bank. Although the debate on whether banks should be allowed to issue their own banknotes took mainly place during the nineteenth century, the corresponding questions resonate until today, as competition between privately created money occurs nowadays simply with e.g. demand deposits. Furthermore, the development of cryptocurrencies has recently renewed the attention to the possibilities and limitations of a competitive money supply (see e.g. Fernandez-Villaverde \& Sanches, 2019).

Switzerland's free-banking history is particularly important, because it can be subdivided into a period with more or less unfettered competition between 1826 and 1881 , and a period with strictly regulated competition between 1881 and 1907 (Baltensperger \& Kugler, 2017, ch.8; Paillard, 1909, pp.189ff.). Herger (2021)

*Correspondence: nils.herger@szgerzensee.ch

Study Center Gerzensee, Dorfstrasse 2, P.O. Box 21, 3115 Gerzensee, Switzerland provides a theoretical account of the differences between a regulated and an unregulated free-banking regime. According to the current assessment of Switzerland's free-banking history, the corresponding economic experiences differed markedly. In particular, Weber (1988; 1992) suggests that the more or less unregulated regime was a success story, as it gave rise to a stable papermoney system. Conversely, according to Neldner (2003), the regime after 1881 was doomed to failure, because banknote regulation undermined the self-discipline against overissuing, which led to a depreciation of the Swiss franc and, in turn, paved the way for the establishment of a banknote monopoly under the auspices of the Swiss National Bank (SNB).

This paper provides a historical reinterpretation of the Swiss experiences with regulated free banking. In particular, to understand why banknote regulation was introduced, it should not be overlooked that unfettered competition can keep the monetary system fragmented, or disintegrated (Friedman \& Schwarz, 1986). As long as multiple banknotes of different quality circulated alongside each other, transaction and inspection costs were relatively high, which undermined the functions of paper money as broadly 
accepted means of payment and commonly recognised unit of account (see also Baltensperger, 2012, p. 279). Against this background, it is not surprising that Switzerland lagged behind in the development of paper money, when compared with other industrialised countries (see e.g. Ritzmann, 1973, pp.37ff.). The lack of an integrated market for paper money could only be overcome through government intervention turning banknotes into a homogenous product and a commonly accepted means of payment.

To avoid the political controversies that arose as regards the foundation of a central note-issuing bank, government intervention into Switzerland's banknote market occurred initially in the form of the Federal Banknote Act of 1881. This piece of legislation turned paper money into a qualitatively more or less homogenous product, by obliging Swiss note issuers to convert, on demand, all banknotes at par value, and by imposing minimum-reserve requirements. It soon turned out that this type of regulation is no panacea. Rather, the decades after 1881 were characterised by an ongoing struggle to maintain an adequate supply of paper money within the constraints of the Federal Banknote Act. In this regard, Neldner (2003) has emphasised the risk of overissuing. Yet, when inspecting the amount of banknotes in circulation and consulting indirect empirical measures, such as the development of inflation, interest rates, and exchange rates, there are reasons to doubt that Switzerland's regulated free-banking system necessarily suffered from endemic and irreparable overissuing. However, even if adequate rules against overissuing were imposed, the Federal Banknote Act still created another quantitative problem; namely the lack of a sufficiently flexible-or what was then called "elastic"-banknote supply. This issue was emphasised by numerous observers at the time, including Kalkmann (1900), Gygax (1901), Paillard (1909), and Jöhr (1915). After 1881, this meant that e.g. seasonal money-demand fluctuations were, arguably, only partially accommodated by changes in supply. Historically, it was impossible to solve the problem of supplying an adequate quantity of paper money while retaining the regulated free-banking system. Therefore, the SNB was established in 1907 to provide, among other things, homogenous Swiss banknotes in a flexible manner.

The paper is organised as follows. As a "prologue", Sect. 2 briefly discusses the unfettered regime between 1826 and 1881. Section 3 turns to the historical and empirical aspects of the regulated regime between 1881 and 1907. As an "epilogue", Sect. 4 sketches the role of central note issuing and the historical path towards the foundation of the SNB in 1907. Finally,
Sect. 5 draws some general conclusions from Switzerland's experiences with a free-banking system.

\section{Prologue: unfettered banknote competition between 1826 and 1881}

This section discusses Switzerland's free-banking history between 1826 and 1881. In contrast to the establishment of officially supported central banks in neighbouring France (in 1800), Austria-Hungary (in 1816), Germany (in 1876), and Italy (in 1893), in Switzerland it was not until the foundation of the Swiss National Bank (SNB) in 1907 when dozens of note-issuing banks lost the right to issue paper money (see e.g. Jöhr, 1915). This did not imply that they could supply paper money in an arbitrary manner, because banknotes represented promises to pay, on demand, a specific amount of currency; at the time monetary metal in the form of bullion or coins. However, until the middle of the nineteenth century, Swiss banks were even free to choose the currency into which their notes should be converted (see Baltensperger \& Kugler, 2017, pp.134-135). Due to the lack of a national currency as well as the low quality of the cantonal monetary systems, early Swiss banknotes were typically denominated in foreign units, such as the French franc or the Brabant thaler (Weber, 1988, p.460).

Until the foundation of the modern Swiss Confederation in 1848, currency and money fell into the jurisdiction of the cantons (Jöhr, 1915, pp.15ff.). However, inspired by the increasing popularity of classical liberal ideas, the Swiss constitution of 1848 called for an integration of the currency system, but preserved the freedom of enterprise in banking (Weber, 1992; Baltensperger, 2012, pp.79ff.). During the subsequent decades, it became clear that this combination encapsulates policy conflicts, which dominated the monetary debate up until the foundation of the SNB. Concretely, in 1850, the Swiss franc was introduced as national currency unit and, in 1860, it became an official replica of the bimetallic system of France. Hence, one franc was convertible into $4.5 \mathrm{~g}$ of silver or $0.29 \mathrm{~g}$ of gold, implying an official silver-to-gold exchange rate of 15.5-1 (see Baltensperger \& Kugler, 2017, p.27; Paillard, 1909, p.9). In 1865, this monetary integration was reinforced as Switzerland joined the "Latin Monetary Union", which constituted a multilateral agreement with Belgium, France, and Italy (later also Greece joined) to align their currency systems through the mutual acceptance of coins, which were subject to internationally agreed silverto-gold mint-pars of 15.5-1 (Baltensperger \& Kugler, 2017, pp.26-29; Paillard, 1909, pp.21ff.). Because e.g. Belgian, French, and Swiss franc coins were equivalent, the official exchange rate between these countries stood at one-to-one. The international monetary cooperation of Switzerland went even so far that most Swiss-franc 


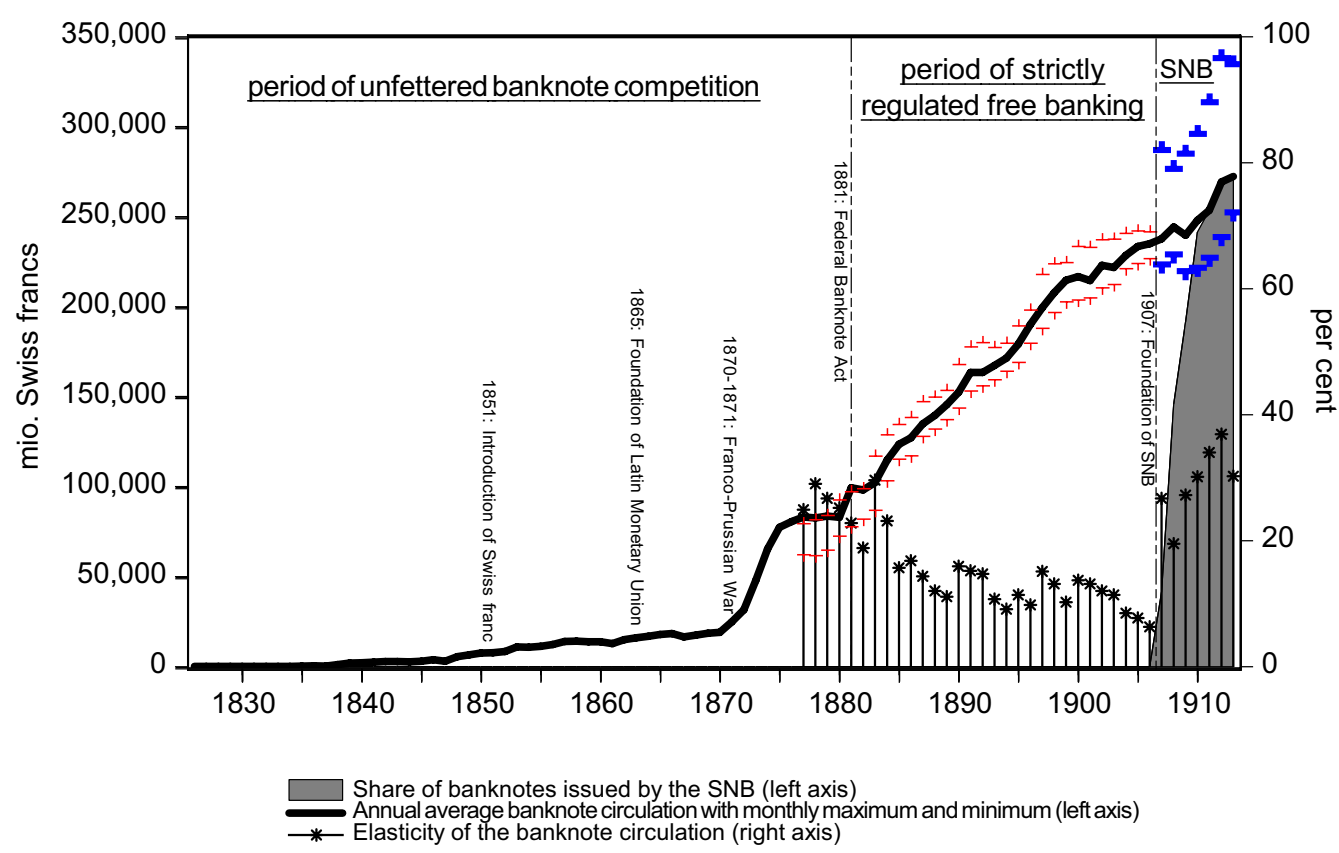

Fig. 1 Banknotes in Switzerland (1826-1913). Notes: The data have an annual frequency and cover the 1826-1913 period. Banknote circulation refers to the annual average across months as reported by Jöhr (1915, pp.496-497). The corresponding monthly maxima, which are denoted by $\perp$ and occurred usually in December, and minima, which are denoted by T and occurred usually in February or March, are also taken from Jöhr (1915, p.500). Between 1877 and 1882, the corresponding data do not cover all note-issuing banks (Jöhr, 1915, p.415). Following Jöhr (1915, p.500), the annual "elasticity of the banknote circulation" is reported in terms of the spread (e.g. the difference between the maximal and the minimal circulation as a percentage of the average banknote circulation during a given year)

coins were minted in France (Baltensperger, 2012, p.82). In contrast to the standardisation in coinage, the Swiss paper-money system remained highly fragmented. Although the introduction of a national currency abolished competition as regards denomination, in the sense that banknotes convertible into Swiss francs became the norm, the cantons retained the responsibility for banking supervision and licensing (Jöhr, 1915, pp.80ff.). None of the dozens of incorporated commercial banks, publicly supported cantonal banks, and local savings banks competing in issuing paper money obtained a market share of more than 25\% (Weber, 1992, p.192). Market entries and exits of note-issuing banks remained quite common after 1850 (Jöhr, 1915, pp.64ff.; Weber, 1992, p.191). Reflecting a widespread laisser-faire attitude, by and large unfettered banknote competition continued until the 1880s (see Baltensperger \& Kugler, 2017, pp.135ff.).

In Switzerland, the period of more or less unfettered banknote competition was characterised by an underdeveloped, and fragmented paper-money system. Banknotes of different quality and with relatively high denominations circulated mainly locally, and represented a store of value, rather than a broadly accepted means of payment (Paillard, 1909, p.190; Jöhr, 1915, pp.80ff.). Figure 1 provides an overview of the development of paper money in Switzerland between 1826 and 1913. Despite the rapid industrialisation and integration of the Swiss economy during the nineteenth century, there was virtually no growth in the amount of banknotes in circulation after they were first issued in 1826. It was not until the 1870s, when a marked increase in the popularity of paper money occurred. ${ }^{1} \mathrm{~A}$ major cause for this increase was the Franco-Prussian War between 1870 and 1871 (Weber, 1992, pp.201-202). Although Switzerland was temporarily cut off from the French money market and the currency reserves of the Banque de France, which resulted in a severe liquidity crisis in 1870, the following years witnessed an economic boom, associated with an upsurge in money demand, in the German-speaking countries of Europe (Baltensperger, 2012, pp.86-87; Weber, 1992, p.202). Furthermore, the aftermath of the Franco-Prussian War saw the advent of the classical gold standard as international currency system (Eichengreen, 2008, pp.15ff.). From the mid 1870s onwards,

\footnotetext{
${ }^{1}$ This increase is also reflected in a doubling of the share of banknotes in M1 from around $10-20 \%$ during the early 1870 s. Conversely, during the second part of the nineteenth century, a steady decline in the importance of coins and a corresponding increase in the share of demand deposits in M1 occurred (Gerlach \& Kugler, 2018, p.3).
} 


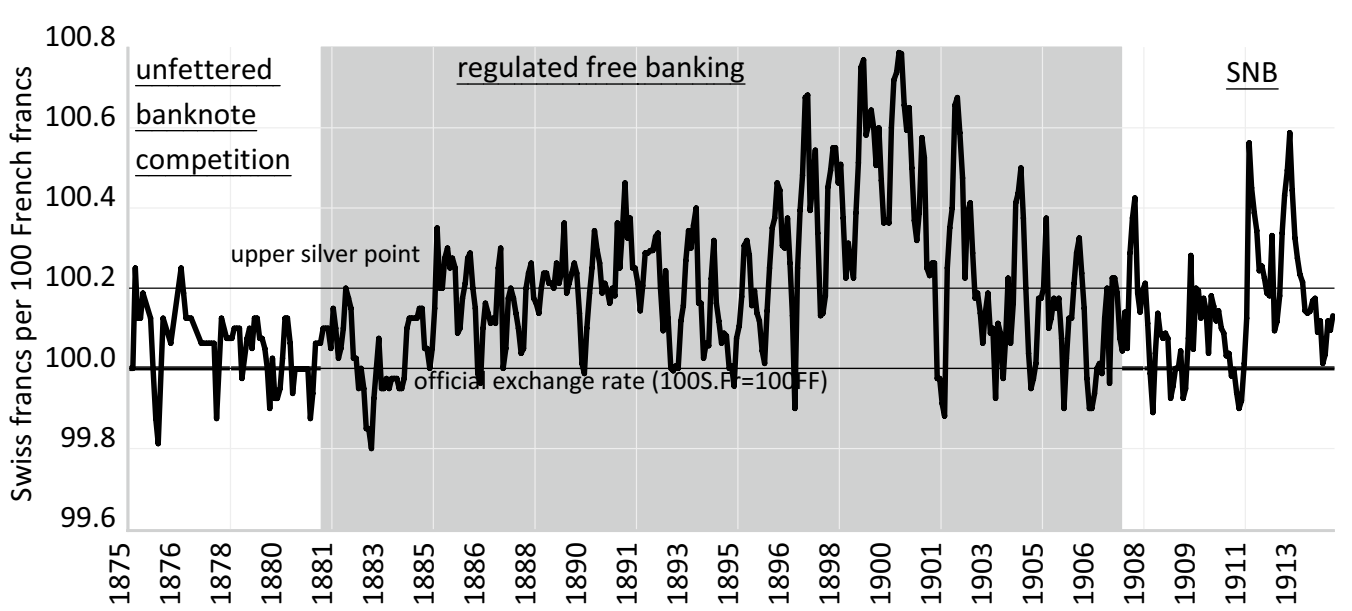

Exchange rate in Zurich on Paris

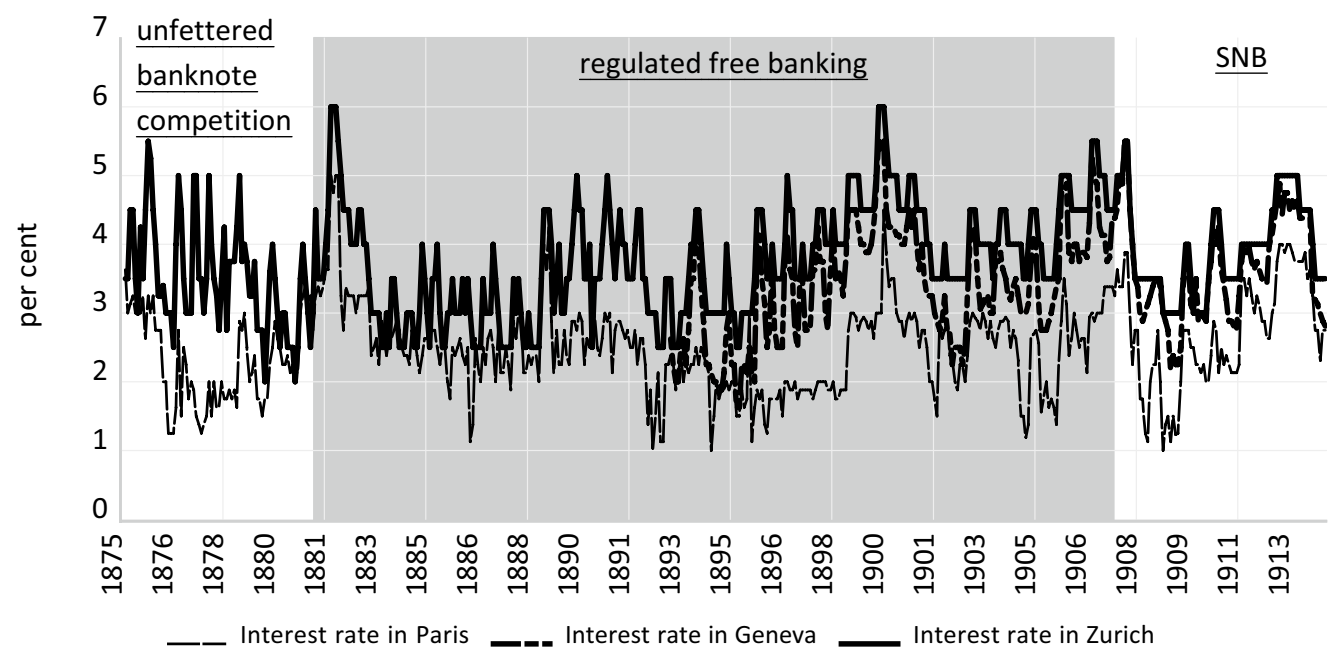

Fig. 2 Exchange rate and interest rates in Switzerland (1875-1914). Notes: The data refer to the last Saturday of the month and cover the 1875 (January) to 1914 (June) period. In the top panel, the exchange rate between Swiss and French francs refers to the market rate on bills of exchange in Zurich on Paris (average between bid and ask rate). The data have been compiled from Kalkmann (1900, pp.98-137) for the years between 1880 and 1900, and the newspaper "Neue Zürcher Zeitung" (NZZ) for other years. In the bottom panel, the (private) interest rates for Paris and Geneva (covering the years from 1893 onwards) refer to the quotations of discount rates in the open money market as reported by Neal and Weidenmier (2003). For Zurich, the interest rate refers to the discount rate of the bank "Credit Suisse" and has been collected from Kalkmann (1900, pp.140-179) for the years between 1880 and 1900, and the "Neue Zürcher Zeitung" (NZZ) for other years. The data can be downloaded at https://nherger.com/ historical-data/

the corresponding demonetisation of silver was associated with an ongoing decrease of the silver price. For a bimetallic currency, such as the Swiss franc, this activated Gresham's law, with the relatively cheaper silver coins-according to the mint-par-flooding into circulation. However, as silver coins are heavy compared with their value, they were a cumbersome, and hence an unpopular, form of money for settling large transactions. Across the last decades of the nineteenth century, these developments fostered the popularity of Swiss banknotes, which were a close substitute for heavy coins
(Paillard, 1909, p.191; Gygax, 1901, pp.379-380; Ritzmann, 1973, p.42).

\section{Regulated free banking between 1881 and 1907 \\ 3.1 Causes and consequences of the Federal Banknote Act of 1881}

The liquidity crisis during the Franco-Prussian War paved the way for monetary reforms in Switzerland (Jöhr, 1915, pp.133ff.; Ritzmann, 1973, pp.92-93). However, it soon became clear that the time was not ripe for 
a banknote monopoly and the foundation of a central bank. Indeed, even the more modest project to regulate the free-banking system was initially rejected in a popular vote in 1872 . The required amendment of the Swiss constitution was only approved by the voters in 1874, after a clause had been added that explicitly prohibited a government monopoly in paper money (Jöhr, 1915, pp.137-138). Further political conflicts as regards the definition of the minimum-reserve requirement, the privileges of the cantonal banks, and the organisation of the federal supervision of note-issuing banks retarded the enactment of the corresponding legislation for another seven years (Jöhr, 1915, pp.138-143). However, after the introduction of the Swiss franc in 1850, the Federal Banknote Act (Bundesgesetz betreffend die Ausgabe und die Einlösung von Banknoten; Loi fédérale sur l'émission et le remboursement des billets de banque) of 1881 provided the next landmark for the reformation of the free-banking system by essentially replacing unfettered banknote competition with a strictly regulated regime (Baltensperger, 2012, pp.95-97). The corresponding government interventions endeavoured to integrate the paper-money market by introducing commonly accepted, standardised, and secure Swiss-franc banknotes (Paillard, 1909, p.195). Above all, the Banknote Act forced note issuers to convert every Swiss banknote at par. Furthermore, to maintain minimum quality standards, banks were required to cover at least $40 \%$ of their note circulation by metallic reserves, and at least $50 \%$ by equity capital (Baltensperger \& Kugler, 2017, pp.37-38). Finally, the form and design of banknotes was standardised, the freedom of the cantons to raise banknote taxes was curtailed, and federal parliament was given the right to limit the total amount of paper money (see Jöhr, 1915, 143ff.). Yet, the Banknote Act did not grant banknotes a legal-tender status (Baltensperger, 2012, p.100).

As complying with regulation can be costly, it is perhaps not surprising that 7 out of 36 banks stopped issuing notes in 1881 (Jöhr, 1915, p.186). However, the total number of note-issuing banks did not decline during the subsequent decades, because additional publicly supported cantonal banks were founded to foster, among other things, the development of paper money (Weber 1992, pp.195-197). Nevertheless, regulatory interventions can change the nature of competition, by e.g. creating incentives to overissue paper money. In particular, as already pointed out by McCulloch (1831) and Longfield (1840), forcing banks to convert all banknotes at par value destroys the public's incentive to discriminate between different types, or brands, of paper money. As theoretically shown by Klein (1974), currency competition without brand loyalty can undermine the selfdiscipline against overissuing, because the risks of an indiscriminate paper-money supply are partially born by rival note-issuing banks (see also Herger, 2021, p.5). Against this background, Neldner (1996a, 2003) has suggested that the Banknote Act of 1881 necessarily tended to introduce excess into Switzerland's free-banking system.

According to Neldner (2003), the overissuing of paper money was manifested in a conspicuous depreciation of the Swiss franc after the introduction of the Federal Banknote Act in 1881. The top panel of Fig. 2 depicts the relevant exchange rate with the French franc. ${ }^{2}$ Indeed, during the second part of the 1890s, an outstanding weakness of the Swiss franc can be observed. This weakness led to notorious levels of so-called "silver drainage" (Paillard, 1909 , pp.221f.). To understand why a large increase of the exchange rate can entail an outflow of silver, it is important to realise that the Swiss franc was only officially equivalent to the French franc through the mint-par of $S^{*}=100$ (see Sect. 2). In a metallic currency system, market exchange rates $S_{t}$ could deviate up to a certain point from the mint-par without triggering gold or silver arbitrage, because international transfers of monetary metal were costly (see e.g. Eichengreen, 2008, pp.24.ff.). Hence, within a no-arbitrage band, the foreign exchange rate was primarily related with the money-market interest rate, rather than a reflection of gold and silver prices (Herger, 2018). As shown by the bottom panel of Fig. 2, Switzerland's interest rate was often slightly higher than that of France implying a "weakness" of the Swiss franc in terms of an exchange rate slightly above the mint-par (see also Baltensperger, 2012, p.107). ${ }^{3}$ Although there is no apparent increase in the level of these interest rates immediately after the introduction of the Banknote Act in 1881, their spread widened during the second part

\footnotetext{
${ }^{2}$ The exchange-rate data of Switzerland refer to Zurich. Similar patterns arise when looking at the Geneva financial market.

3 Perhaps, a standard interest-parity condition, given by

$$
S_{t}-S_{t}^{*} \approx i_{t}-i_{t}^{F},
$$

helps to clarify these connections. Here, $i_{t}$ denotes the domestic (Swiss) discount rate at time $t$ and $i_{t}^{F}$ the foreign money-market discount rate (e.g. in France). For Switzerland, interest arbitrage occurred mainly with France, because large volumes of bills of exchange were issued to finance Switzerland's indebtedness towards France (Paillard, 1909, pp.228ff.; Geering, 1904). With the data of Paris and Zurich of Fig. 2, and observations below the silver-export point, a standard interest-parity regression yields

$$
\left(S_{t}^{C H}-S_{t}^{*}\right)=\underset{(0.83)}{1.13}+\underset{(0.66)}{1.27}\left(i_{t}-i_{t}^{F}\right) \quad N=174 ; \quad R^{2}=0.02
$$

The slope coefficient of 1.27 , which is close to one and does not differ statistically from this value at any conventionally used level of rejection, is consistent with the interest-parity condition between Switzerland and France. This result concurs with Herger (2018), who found similar patterns between the exchange rates and interest rates of Britain, France, Germany, and the Netherlands during the era of the classical gold standard. 
of the 1890s. Correspondingly, between 1896 and 1902, the exchange rate was almost permanently above the socalled "specie point" (or "silver-export point"), beyond which it became profitable to arbitrage monetary metal. Between Switzerland and France, with a specie point of around 100.20 (Neldner, 2003, p.392), exchanging 100 French francs into, say, 100.20 Swiss francs, approaching a note-issuing bank in Switzerland to exchange this amount at the mint-par into $100.20 \times 4.5=450.9$ $\mathrm{g}$ of silver coins, and export them to end up with 100.2 French francs yielded a sufficiently large profit to cover the corresponding transaction costs (see Kalkmann, 1900, pp.17ff.). ${ }^{4}$ Especially the note-issuing banks located close to the French border (e.g. in Geneva) were heavily exposed to this silver drainage. To fulfill the minimumreserve requirement of the Federal Banknote Act, noteissuers, such as the Banque du Commerce in Geneva, were sometimes forced to reimport, at a higher price, the very silver money they had paid out shortly before (Kalkmann, 1900, p.21; Ritzmann, 1973, p.97). Towards the end of the 1890s, silver drainage inflicted substantial losses on some note-issuing banks. In a small number of cases, branches located near the French border had even to be closed (see Paillard, 1909, pp.223-224).

The drawbacks of the free-banking system became a major subject of the monetary debate in Switzerland around the year 1900. However, it is noteworthy that the reports and books reflecting this debate, including Kalkmann (1900, pp.28ff.), Gygax (1901), Paillard (1909, pp.199ff.), and Jöhr (1915, pp.308ff.), typically identified the lack of "elasticity" of the banknote supply to absorb demand fluctuations, rather than the overissuing emphasised by Neldner (2003), as the main problem (see also Ritzmann 1996, p.200). ${ }^{5}$ Among other things, nineteenth-century financial systems had to deal with seasonal payment fluctuations. For example, the

\footnotetext{
${ }^{4}$ With respect to France, currencies were mainly arbitraged with silver, because the Banque de France charged a premium on gold withdrawals to discourage gold exports (see Kalkmann, 1900, pp.12ff.). It is difficult to quantify the total amount of the corresponding silver outflows, because Switzerland's trade statistics only recorded imports and exports of monetary metal of more than 10 Swiss francs after 1888 (Paillard, 1909, p.217). Because arbitrage also occurred with smaller amounts, the statistical picture of the silver drainage remains highly incomplete (Paillard, 1909, pp.217ff.).

${ }^{5}$ Neldner (1996a, p.189) quotes Jöhr (1915, p.193) to suggest that the weakness of the Swiss franc was at the time attributed to "the flooding of the country with paper money" and the "relentless note-printing press". However, Jöhr (1915, p.193) goes on to argue that "there must be serious doubts as regards the correctness of these claims, if one considers that the average note circulation since the abolishment of the note-issuing right of the old note-issuing banks has not decreased, but [...] continued to increase. The growth of note-issuing, the amount of circulating paper money [...] cannot be the sole cause for the bad state of the currency. I am rather inclined to interpret the quick expansion of the banknote circulation as a consequence of the bad monetary constitution of the country."
}

demand for money in Switzerland regularly increased in June and November, when large amounts of financial securities matured (Paillard, 1909, pp.198-199; Kalkmann, 1900, p.54). In this regard, the regulated free-banking system of Switzerland suffered, arguably, from major frictions by regularly creating an oversupply of paper money during the first half of the year, and a shortage during the second half (see e.g. Kalkmann, 1900, p.29, Nüscheler, 1912, pp.3ff.). The free-banking model of Herger (2021, pp.3-5) suggests indeed that the introduction of a binding minimum-reserve requirement can lower the elasticity of the money supply. Unsurprisingly, this "inelasticity" of paper money was seen as a major impediment for trade and investment (Paillard, 1909, p.225: Baltensperger, 2012, p.103). Against this background, relatively high interest rates can also be interpreted as a byproduct of expensive regulatory constraints, such as minimum-reserve requirements, and, hence, as a reflection of broader inefficiencies within the free-banking system. For the case of the United States before the foundation of the Federal Reserve System in 1914, Miron (1986) provides indeed a theoretical framework to show that free-banking systems can suffer from relatively large seasonal interest-rate fluctuations.

\subsection{Was overissuing and/or an inelastic banknote supply the problem?}

As mentioned above, overissuing and an inelastic banknote supply are possible, and not necessarily mutually exclusive, side effects of a regulated free-banking system. From which of these problems Switzerland actually suffered after 1881 is ultimately an empirical question. Further to the historical evidence, this section endeavours to shed some light on this question by looking at the available economic and financial data.

In general, it is difficult to directly gauge the extent of overissuing from the amount of banknotes in circulation, because in a market for paper money, an oversupply refers to an equilibrium level of demand, which cannot be separately measured from the data (Neldner, 2003, p.391). Therefore, as mentioned in Sect. 3.1, Neldner (2003) has employed indirect measures, and especially the exchange rate of the Swiss franc, to suggest that overissuing was an outstanding feature of Switzerland's free-banking system between 1881 and 1907 (see also Baltensperger, 2012, pp.109-111; Baltensperger \& Kugler, 2017, p.44). However, an inspection of the corresponding data across a longer time horizon including the early 


\section{(See figure on next page.)}

Fig. 3 Empirical evidence on overissuing. Notes: The data have an annual frequency. The annual average of the exchange rate between the Swiss and the French franc of the top panel covers the 1851-1913 period and is taken from Table 21 of Jöhr (1915, p.509), who has compiled these data from various sources (see Jöhr, 1915, p.418). The consumer-price index of the top panel covers the 1826-1913 period and has been taken from Table H39 of the 2012 edition of the Historical Statistics of Switzerland (see www.hsso.ch). In the middle panel, the banknotes in circulation (e.g net of banknotes held as reserves by note-issuing banks) per capita have been compiled from Tables DB11 and DB15 of Flandreau and Zumer (2004). The price indices of the bottom panel have been taken from Table DB13 of Flandreau and Zumer (2004). To reflect the effect of regulated free banking, these indices have been re-based, such that $1881=100$

history of the Swiss franc, as well as international comparisons cast some doubt on this view.

In particular, as depicted by the top panel of Fig. 3, the annual average of the Swiss-to-French-franc exchange rate was remarkably stable across the freebanking periods with unfettered competition and strict banknote regulation (see also Fig. 2). ${ }^{6}$ Substantial deviations from the par value of 100 , and hence possibilities for arbitrage with monetary metal, such as silver, arose typically only in times of political and economic crises. Above all, the Franco-Prussian War between 1870 and 1871 was associated with a large appreciation of the currency of nonbelligerent Switzerland. In a similar vein, the aggravated weakness of the Swiss franc between 1896 and 1902 was rather exceptional, and has been attributed by Kalkmann (1900, pp.25ff.) and Paillard (1909, pp.226ff.) to a balance-of-payments crisis, rather than an ongoing overissuing of paper money. It is indeed well known that the future of bimetallic currencies, including the Swiss franc, hung in the balance after the United States had renounced a policy to remonetise silver in 1893 (Friedman \& Schwarz, 1963, pp.104ff.). The transition of the Indian rupee, which was an important silver currency, to a gold-exchange standard during the second part of the 1890s added to this uncertainty (Herger, 2019). Taken together, the years during which the future of currency systems that were at least partially based on silver was unclear, overlap with Switzerland's silver-drainage period. When the regulated regime would have necessarily suffered from overissuing, it is unclear why notoriously high levels of the exchange rate and silver drainage did not occur throughout the 1880 s and 1890 s.

Furthermore, as shown by the middle panel of Fig. 3 for the years between 1880 and 1913, the amount of paper money per capita in Switzerland was substantially lower than in Belgium and France, which had very similar currency systems (see Sect. 2). As already observed by Wolf (1888, pp.80-81) and Paillard (1909, pp.196ff.), this relatively low amount of paper money casts doubt

\footnotetext{
${ }^{6}$ Indeed, the exchange-rate mean of Fig. 3 during the regulated period of free banking (1881-1906) is not significantly higher, with a t-value of 0.83 , than the mean of the earlier years.
}

on the hypothesis of an overissuing caused by the regulated free-banking system, because French and Belgian banknotes had long been a monopoly of, respectively, the Banque de France and the Banque Nationale de Belgique. Then again, it should not be overlooked that the concept of "overissuing" relates to a benchmark money demand, which is not per se constant across countries and time and, probably, was not only a function of population size. $^{7}$

Likewise, an overissuing of paper money might be associated with relatively high rates of inflation. However, the decades before the year 1900 were actually characterised by entrenched deflation. Of course, these average price decreases were an international phenomenon (see e.g. Eichengreen, 2008, p.18). Nevertheless, the fact that there was, if anything, more deflation in Switzerland than in the other countries of the Latin Monetary Union as well as in neighbouring Austria-Hungary and Germany (see bottom panel of Fig. 3) does not sit well with the notion of an overissuing caused by the regulated free-banking system (Neldner, 1996b, p.204; Ritzmann, 1996, p.199). When looking at the aggregate price development within Switzerland between 1826 and 1913, as depicted by the top panel of Fig. 3, it is also the case that the period of strict banknote regulation did not give rise to significantly higher levels of inflation. ${ }^{8}$

Finally, Article 9 of the Banknote Act of 1881 gave Switzerland's parliament the right to limit, at any time and according to the circumstances, the total amount of paper money (Jöhr, 1915, pp.142, 144). Hence, if overissuing was a pervasive problem, Ritzmann (1996, p.200)

\footnotetext{
7 Attempts to reconstruct the demand for banknotes would be prone to the vagaries of finding a correct and comparable model across countries and time. The corresponding analysis of Gerlach and Kugler (2018, pp.6-7) refers only to the case of Switzerland, and therefore does not lend itself to the international comparison of the middle panel of Fig. 3. However, as regards a comparison of money demand across time, Gerlach and Kugler (2018, pp.6-7) have only found scant evidence for an instable money-demand function around the year 1881. Furthermore, between 1870 and 1890, the share of banknotes in M1 followed a linear trend (2018, p.3). Apparently, the introduction of the Federal Banknote Act did not immediately give rise to a highly different money-demand pattern.

8 The mean of the consumer-price index of Fig. 3 does not differ significantly, with a $t$ value of 0.26 , between the periods with unfettered banknote competition (1826-1881) and strict banknote regulation (1881-1906).
} 


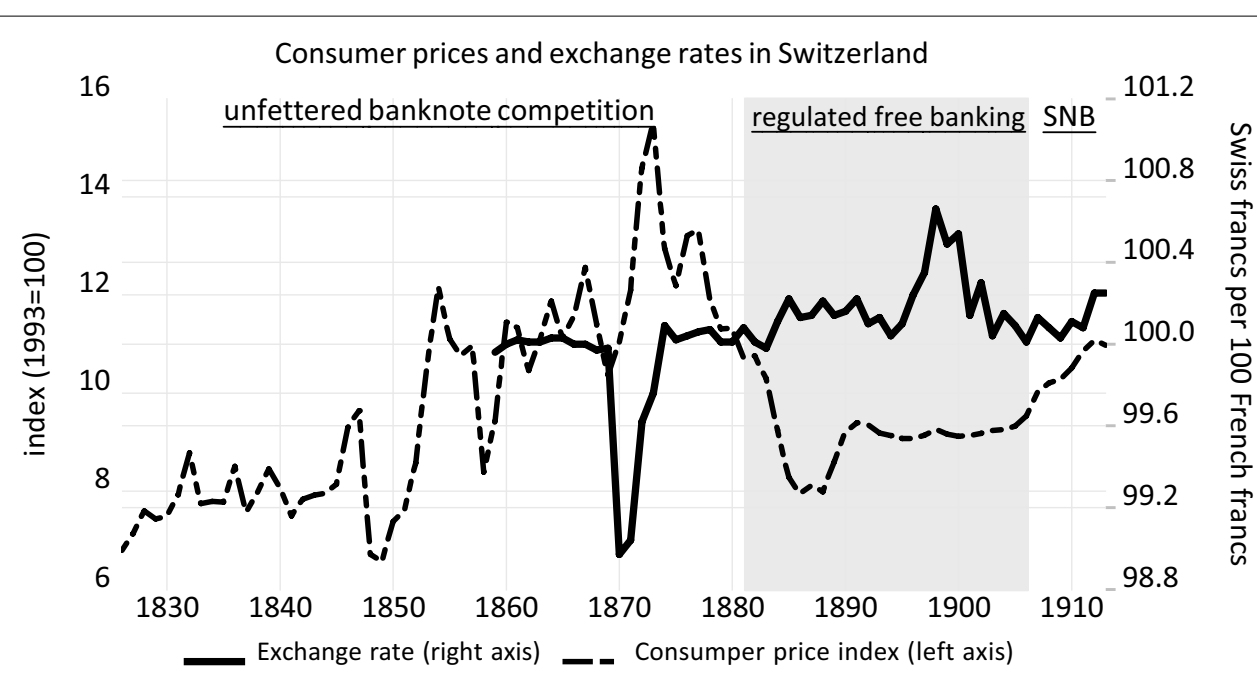

Banknotes per capita in Belgium, France, and Switzerland (1880-1913)
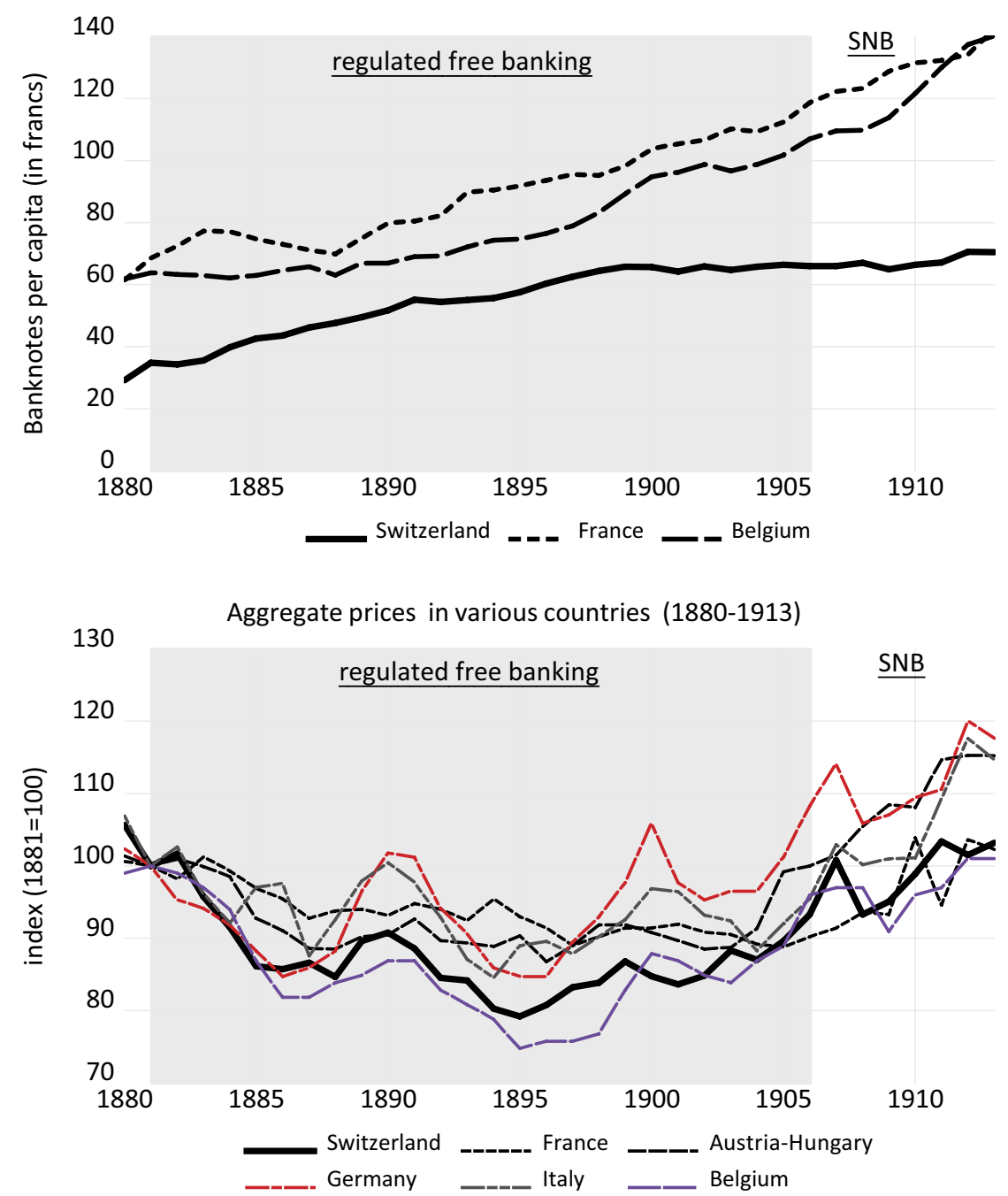

Fig. 3 (See legend on previous page.) 
Table 1 Analysis of variance (ANOVA) of the discount-rate in Switzerland (1875-1914)

\begin{tabular}{llllll}
\hline $\begin{array}{l}\text { Period: } \\
\text { Sample: }\end{array}$ & $\begin{array}{l}\text { Free banking } \\
\text { January 1875-May 1907 }\end{array}$ & $\begin{array}{l}\text { SNB } \\
\text { June 1907- } \\
\text { June 1914 }\end{array}$ & $\begin{array}{l}\text { Unregulated free banking } \\
\text { January 1875-March 1881 }\end{array}$ & $\begin{array}{l}\text { Regulated free banking } \\
\text { April 1881-May 1907 }\end{array}$ & $\begin{array}{l}\text { SNB } \\
\text { June } \\
\mathbf{1 9 0 7 - J u n e} \\
\mathbf{1 9 1 4}\end{array}$ \\
& $\mathbf{( 1 )}$ & $\mathbf{( 2 )}$ & $\mathbf{( 3 )}$ & $\mathbf{( 4 )}$ & $\mathbf{( 5 )}$ \\
\hline $\begin{array}{l}\text { Standard deviation } \\
\text { Levene test }\end{array}$ & $\begin{array}{l}0.799 \\
11.60^{* * *}\end{array}$ & 0.688 & 0.736 & 0.816 & 0.688 \\
\hline
\end{tabular}

The discount rate is at a weekly frequency and refers to the data in Zurich as reported in Fig. 2 . The total standard deviation across the sample with $T$ observations between the beginning of January 1875 and the end of June 1914 equals 0.786 . The Levene test is based on an analysis of variance (ANOVA) across $G$ groups of the absolute difference from the mean (Levene, 1960). The test statistic is F-distributed with the number of degrees of freedom in the numerator equal to $G$, and $T-G$ in the denominator. The null hypothesis is that the subgroup variances are equal. A rejection at the $10 \%$ level is marked by ${ }^{*}$, at the $5 \%$ level by ${ }^{* *}$, and at the $1 \%$ level by ***

has raised the question as why the banknote quotas were not simply tightened. Compared with the abolishment of the free-banking system, which was highly controversial (see Sect. 4), this would have been a relatively straightforward policy measure.

Turning to the evidence as regards an inelastic supply of paper money, the introduction of the Banknote Act in 1881 seems indeed to have been followed by a corresponding decline. At least, according to Fig. 1, the spread between the maximum and minimum amount of banknotes in circulation relative to the average amount during a given year more than halved from a value above $20 \%$ before 1881 , to less than $10 \%$ after the year 1900 . Although the corresponding data do unfortunately not go back before the 1870s, they are consistent with the hypothesis that regulatory constraints, such as minimum-reserve requirements, exacerbated the inelastic supply of money.

According to Jöhr (1915, p.204), the low elasticity was also manifested in a longer duration of banknotes in circulation during the regulated period. For the Bank in Basel, and across various banknote denominations, Weber (1992, p.193) reports indeed an ongoing increase of the average duration of banknotes in circulation by a factor of three and more between 1880 and 1906. However, the corresponding data do not provide a comprehensive picture, because the Bank in Basel accounted for less than $20 \%$ of Swiss banknotes (Jöhr, 1915, pp.424425 ; 496-497). ${ }^{9}$

\footnotetext{
${ }^{9}$ Kalkmann (1900, p.28) suggests that banknote taxes also led to an inflexible supply of paper money. Because these taxes had to be paid on the basis of emission quotas, rather than on the amount of banknotes actually put into circulation, note-issuing banks had arguably an incentive to fully exhaust their quotas (see also Baltensperger, 2012, p.103; Baltensperger \& Kugler 2017, pp.41-42). Then again, it would have been easier to remedy this problem by amending the Banknote Act of 1881, rather than entering the political controversies of establishing a central note-issuing bank. Furthermore, it was quite common to collect banknote taxes based on emission quotas before 1881 (see Jöhr, 1915, p.83). Hence, taxes can probably not explain why the flexibility in the supply of banknotes declined after 1881 .
}

According to Miron (1986), an inelastic paper-money supply can manifest itself in relatively high levels of nominal interest-rate fluctuations. When considering the shift of standard money supply and demand curves, it is indeed plausible that e.g. the discount rate of note-issuing banks responds heavier to seasonal demand fluctuations when corresponding supply adaptations are restricted by the minimum-reserve requirement of a regulated free-banking system. To test this hypothesis within the current context, Table 1 reports the results for an analysis of variance (ANOVA) of the discount rate in Switzerland during the free-banking system, and the years following the foundation of the SNB. In particular, columns 1 and 2 compare the standard deviations of the discount rate in Zurichas shown in Fig. 2-for, respectively, the weeks between the beginning of January 1875 and the establishment of the SNB in June 1907, and the subsequent period until the outbreak of World War I in July 1914. Columns 3-5 provide an additional breakdown of the free-banking system between the regime with unfettered competition before the introduction of the Banknote Act in March 1881, and the regulated regime thereafter. However, across all these periods, standard Levene tests provide statistical evidence that Switzerland's free-banking system suffered from significantly higher levels of discount-rate volatility, than the period thereafter. The corresponding standard deviation is particularly large during the regulated period. ${ }^{10}$

Taken together, the evidence suggests that not only overissuing, but also an inelastic paper-money supply was a possible side effect of Switzerland's free-banking system after the introduction of strict banknote regulation in 1881 . The next section briefly discusses how these problems paved the way for the foundation of the SNB.

\footnotetext{
${ }_{10}$ This result is robust to using different test statistics (such as the Bartlett and Brown-Forsythe test), turning to the monthly frequency of the data, including additional observations back to 1857 , and employing the discount rate in Geneva. For the sake of brevity, these robustness checks are not reported here, but are available on request.
} 


\section{Epilogue: the end of free banking and the foundation of the Swiss National Bank}

This section turns to the end of free banking and sheds light on the reasons why central note-issuing was introduced. In Switzerland, the impotence of the regulated free-banking system to stabilise the exchange rate during the period of notorious silver drainage between 1896 and 1902 plaid a major role in overcoming the opposition against central-note issuing (see Paillard, 1909, p.225; Ritzmann, 1973, p.96; Baltensperger \& Kugler, 2017, pp.42-43). In particular, whereas a constitutional amendment seeking a banknote monopoly for the Swiss confederation was already passed in 1891, proposed legislation to establish a state-owned central bank was rejected in a popular referendum in 1897 (Jöhr, 1915, pp.251ff.). The opponents successfully invoked the dangers of a centralisation of government power in monetary affairs (Jöhr, 1915, pp.259ff.). However, a revised draft, which proposed a stock-traded central bank with a mixed ownership by the cantons, the former note-issuing banks, and private investors, succeeded in 1905. The SNB opened its counters in 1907, which marked the end of free banking in Switzerland (see Baltensperger, 2012, pp.101103; Baltensperger \& Kugler, 2017, pp.45-49.).

The experiences with the transition towards a public banknote monopoly in 1907 lend further support to the hypothesis that the Swiss free-banking system lacked an elastic money supply. In particular, the SNB was quickly able to replace private banknotes as well as to raise their maximum amount in circulation during a given year (see Fig. 1). In other words, the elasticity of the money supply was increased. Conversely, when free banking would necessarily result in overissuing, the foundation of the SNB should have reduced the amount of banknotes in circulation (or at least lowered the corresponding growth rate). However, Fig. 1 does not suggest that such a reduction took place after 1907.

Against this background, it is perhaps not surprising that the original legal mandate instructed the SNB to regulate the money market, to increase the efficiency of the payment system, and to provide Swiss-franc banknotes in a flexible manner (Paillard, 1909, pp.231ff.; Baltensperger, 2012, pp.134-135). In particular, Article 2 of the Federal Act on the Swiss National Bank of 1905 said that "the National Bank has the main task of regulating the circulation of money within the country and facilitating the settlement of payments". According to Article 18, banknotes had to be issued "according to the needs of commerce" (see also Jöhr, 1915, pp.303ff.). Hence, similar to the Federal Reserve System of the United States, the SNB was initially set up to serve as a kind of reserve bank, which was supposed to, among other things, increase the flexibility of the money supply (see Bordo, 2018, p.104).

\section{Conclusion}

This paper has offered a reinterpretation of Switzerland's historical experiences with a free-banking system during the nineteenth and early twentieth century. Hitherto, the literature has only partially acknowledged the entrenched economic trade-offs, which affected the regimes with more or less unfettered banknote competition between 1826 and 1880 , and strictly regulated competition between 1881 and 1907. In particular, although the largely unregulated regime before 1881 gave Swiss note issuers a large degree of freedom and ample incentives to meet the demand for banknotes, unfettered competition also led to a fragmented paper-money system. As banknotes of different quality circulated alongside each other, they only partially fulfilled the key function of money as a universally accepted means of payment. To overcome this problem, the Federal Banknote Act of 1881 imposed common quality standards and, hence, introduced homogenous Swiss-franc banknotes. However, the regulatory interventions to achieve this, such as minimum-reserve requirements or mutual-conversion rules for banknotes, adversely affected their quantity. In this regard, the tendency of Switzerland's regulated free-banking system for overissuing has long been recognised. However, it should not be overlooked that another problem, namely the lack of an elastic paper-money supply to match seasonal fluctuations in money demand, was also important, as emphasised by many observes at the time. In any case, historically, the foundation of the Swiss National Bank (SNB) in 1907 provided an escape from a free-banking system that was apparently unable to offer standardised Swiss-franc banknotes in a adequate manner. Thanks to the monopoly in paper money, and without a profit-maximising motive, the SNB quickly managed to issue homogenous banknotes according to the needs of commerce. Of course, the introduction of central-note issuing was also associated with an increasing concentration of public power in monetary affairs. The corresponding caveats and debates are well known.

Although this paper has focused on the history of banknote competition in Switzerland, the corresponding experiences have potential implications for modern monetary systems. In particular, these experiences might be a reflection of a general problem to supply homogenous forms of money in a flexible manner through purely private competition. Despite the progress in financial technology since the nineteenth century, there is no obvious reason why this economic problem, which apparently arose during the free-banking period in Switzerland, cannot beset modern forms of private money, such as cryptocurrencies.

\section{Reviewers' Appendix: Additional results referring to footnote 10}

See Tables 2, 3, 4 and 5. 
Table 2 Analysis of variance (ANOVA) of the discount-rate in Switzerland (1875-1914)

\begin{tabular}{llllll}
\hline $\begin{array}{l}\text { Period: } \\
\text { Sample: }\end{array}$ & $\begin{array}{l}\text { Free banking } \\
\text { January 1875-May 1907 }\end{array}$ & $\begin{array}{l}\text { SNB } \\
\text { June 1907- } \\
\text { June 1914 }\end{array}$ & $\begin{array}{l}\text { Unregulated free banking } \\
\text { January 1875-March 1881 }\end{array}$ & $\begin{array}{l}\text { Regulated free banking } \\
\text { April 1881-May 1907 }\end{array}$ & $\begin{array}{l}\text { SNB } \\
\text { June } \\
\mathbf{1 9 0 7 - J u n e} \\
\mathbf{1 9 1 4}\end{array}$ \\
& $\mathbf{( 1 )}$ & $\mathbf{( 2 )}$ & $\mathbf{( 3 )}$ & $\mathbf{( 4 )}$ & $\mathbf{( 5 )}$ \\
\hline Standard deviation & 0.799 & 0.688 & 0.736 & 0.816 \\
Levene test & $11.60^{* * *}$ & & $10.05^{* * *}$ & \\
Bartlett test & $12.51^{* * *}$ & & $17.16^{* * *}$ & \\
Brown-Forsythe test & $5.76^{* * *}$ & & $6.06^{* * *}$ & \\
\hline
\end{tabular}

Different ANOVA tests

The discount rate is at a weekly frequency and refers to the data in Zurich as reported in Fig. 2. The standard deviation across the sample with $T$ observations between the beginning of January 1875 and the end of June 1914 equals 0.786 . The various analysis of variance (ANOVA) tests refer to differences across $G$ groups. The null hypothesis is that the subgroup variances are equal. A rejection at the $10 \%$ level is marked by ${ }^{*}$, at the $5 \%$ level by ${ }^{* *}$, and at the $1 \%$ level by ${ }^{* *}$

Table 3 Analysis of variance (ANOVA) of the discount-rate in Switzerland (1872-1914)

\begin{tabular}{|c|c|c|c|c|c|}
\hline Period: & Free banking & SNB & Unregulated free banking & Regulated free banking & SNB \\
\hline \multirow[t]{2}{*}{ Sample: } & $\begin{array}{l}\text { January 1875-May } \\
1907\end{array}$ & June 1907-June 1914 & January 1875-March 1881 & April 1881-May 1907 & $\begin{array}{l}\text { June } \\
1907- \\
\text { June } \\
1914\end{array}$ \\
\hline & (1) & $(2)$ & (3) & (4) & $(5)$ \\
\hline Standard deviation & 0.814 & 0.689 & 0.784 & 0.818 & 0.689 \\
\hline Levene test & $4.0^{* *}$ & & $2.22^{*}$ & & \\
\hline
\end{tabular}

Monthly frequency

The discount rate is at a monthly frequency (last observation of the month) and refers to the data in Zurich as reported in Fig. 2. The standard deviation across the sample with T observations between the beginning of January 1875 and the end of June 1914 equals 0.795 . The Levene test is based on an analysis of variance (ANOVA) across $G$ groups of the absolute difference from the mean (Levene, 1960). The test statistic is F-distributed with the number of degrees of freedom in the numerator equal to $G$, and $T-G$ in the denominator. The null hypothesis is that the subgroup variances are equal. A rejection at the $10 \%$ level is marked by ${ }^{*}$, at the $5 \%$ level by ${ }^{* *}$, and at the $1 \%$ level by ${ }^{* * *}$

Table 4 Analysis of variance (ANOVA) of the discount-rate in Switzerland (1857-1914)

\begin{tabular}{lllll}
\hline $\begin{array}{l}\text { Period: } \\
\text { Sample: }\end{array}$ & $\begin{array}{l}\text { Free banking } \\
\text { January 1875-May 1907 }\end{array}$ & $\begin{array}{l}\text { SNB } \\
\text { June 1907- } \\
\text { June 1914 }\end{array}$ & $\begin{array}{l}\text { Unregulated free banking } \\
\text { January 1875-March 1881 }\end{array}$ & $\begin{array}{l}\text { Regulated free banking } \\
\text { April 1881-May 1907 }\end{array}$ \\
& $\mathbf{( 1 )}$ & $\mathbf{( 2 )}$ & $\mathbf{( 3 )}$ & $\begin{array}{l}\text { SNB } \\
\text { 1907-June } \\
\mathbf{1 9 1 4}\end{array}$ \\
\hline $\begin{array}{l}\text { Standard deviation } \\
\text { Levene test }\end{array}$ & $\begin{array}{l}0.893 \\
24.94^{* *}\end{array}$ & 0.688 & 0.954 \\
$\mathbf{( 5 )}$
\end{tabular}

Sample until 1857

The discount rate is at a weekly frequency and refers to the data in Zurich as reported in Fig. 2. The standard deviation across the sample with $T$ observations between the beginning of January 1857 and the end of June 1914 equals 0.862 . The Levene test is based on an analysis of variance (ANOVA) across $G$ groups of the absolute difference from the mean (Levene, 1960). The test statistic is F-distributed with the number of degrees of freedom in the numerator equal to $G$, and $T$ - $G$ in the denominator. The null hypothesis is that the subgroup variances are equal. A rejection at the $10 \%$ level is marked by ${ }^{*}$, at the $5 \%$ level by ${ }^{*}$, and at the $1 \%$ level by ${ }^{* *}$ 
Table 5 Analysis of variance (ANOVA) of the discount-rate in Switzerland (1892-1914)

\begin{tabular}{|c|c|c|c|c|c|}
\hline Period: & $\begin{array}{l}\text { Free } \\
\text { banking }\end{array}$ & SNB & $\begin{array}{l}\text { Unregulated } \\
\text { free banking }\end{array}$ & $\begin{array}{l}\text { Regulated } \\
\text { free } \\
\text { banking }\end{array}$ & SNB \\
\hline \multirow[t]{2}{*}{ Sample: } & $\begin{array}{l}\text { January } \\
1892- \\
\text { May } \\
1907\end{array}$ & $\begin{array}{l}\text { June } \\
\text { 1907- } \\
\text { June } \\
1914\end{array}$ & $\begin{array}{l}\text { January } \\
\text { 1875-March } \\
1881\end{array}$ & $\begin{array}{l}\text { April 1881- } \\
\text { May } 1907\end{array}$ & $\begin{array}{l}\text { June } \\
1907- \\
\text { June } \\
1914\end{array}$ \\
\hline & (1) & $(2)$ & (3) & (4) & (5) \\
\hline $\begin{array}{l}\text { Standard } \\
\text { deviation }\end{array}$ & 0.836 & 0.751 & na. & 0.836 & 0.751 \\
\hline $\begin{array}{l}\text { Levene } \\
\text { test }\end{array}$ & $6.08^{* *}$ & & $6.08^{* *}$ & & \\
\hline
\end{tabular}

\section{Geneva discount rate}

The discount rate is at a weekly frequency and refers to the data in Geneva. The standard deviation across the sample with $T$ observations between the beginning of January 1875 and the end of June 1914 equals 0.786 . The Levene test is based on an analysis of variance (ANOVA) across $G$ groups of the absolute difference from the mean (Levene, 1960). The test statistic is F-distributed with the number of degrees of freedom in the numerator equal to $G$, and $T-G$ in the denominator. The null hypothesis is that the subgroup variances are equal. A rejection at the $10 \%$ level is marked by ${ }^{*}$, at the $5 \%$ level by ${ }^{*}$, and at the $1 \%$ level by ***

\section{Abbreviations}

FF: French Francs; S.Fr: Swiss Francs; SNB: Swiss National Bank.

\section{Acknowledgements}

This paper has benefited from valuable comments and suggestions by two anonymous reviewers, Ernst Baltensperger, and Heinz Zimmermann.

\section{Author's contributions}

Author read and approved the final manuscript.

\section{Funding}

Not applicable.

\section{Availability of data and materials}

The data used during the current study are available from the author on request.

\section{Declarations}

\section{Competing interests}

The author declares that he has no competing interests.

Received: 22 March 2021 Accepted: 25 October 2021

Published online: 13 November 2021

\section{References}

Baltensperger, E. (2012). Der Schweizer Franken - Eine Erfolgsgeschichte. Die Währung der Schweiz im 19. und 20. Jahrhundert. NZZ Libro.

Baltensperger, E., \& Kugler, P. (2017). Swiss Monetary history since the Early 19 century. Cambridge University Press.

Bordo, M. D. (2018). Currency competition in Switzerland. Aussenwirtschaft, 68, 101-108.

Eichengreen, B. (2008). Globalizing capital: A history of the international monetary system. Princeton University Press.

Fernandez-Villaverde, J., \& Sanches, D. (2019). Can currency competition work? Journal of Monetary Economics, 106, 1-15.
Flandreau, M., \& Zumer, F. (2004). The making of global finance 1880-1913. OECD Development Center Studies.

Friedman, M., \& Schwarz, A. (1963). A monetary history of the United States, 1867-1960. Princeton University Press.

Friedman, M., \& Schwarz, A. (1986). Has Government any role in money? Journal of Monetary Economics, 17, 37-62.

Geering, M. (1904). Die Verschuldung der Schweiz an Frankreich. Schulthess.

Gerlach, S., \& Kugler, P. (2018). Money demand under free banking: Switzerland 1851-1906. Swiss Journal of Economics and Statistics, 154, 1-8.

Gygax, P. (1901). Kritische Betrachtungen über das Schweizerische Notenbankwesen mit Beziehung auf den Pariser Wechselkurs. Müller.

Herger, N. (2018). Interest-parity conditions during the era of the classical gold standard (1880-1914)_Evidence from the investment demand for bills of exchange in Europe. Swiss Journal of Economics and Statistics, 154(9), $1-12$.

Herger, N. (2019). Testing the interest-parity condition with Irving Fisher's example of Indian rupee and sterling bonds in the London financial market (1869-1906), Financial History Review, 21-42.

Herger, N. (2021). Unregulated and regulated free banking: Evidence from the case of Switzerland (1826-1907). Explorations in Economic History (forthcoming). https://doi.org/10.1016/j.eeh.2021.101423.

Jöhr, A. (1915). Die Schweizerischen Notenbanken, 1826-1913. Orell Füssli.

Kalkmann, P. (1900). Untersuchungen über das Geldwesen der Schweiz und die Ursachen des hohen Standes der auswärtigen Wechselkurse. Zollikofersche Druckerei.

Klein, B. (1974). The competitive supply of money. Journal of Money, Credit, and Banking, 6, 423-53.

Levene, H. (1960). Robust tests for equality of variances. In I. Olkin \& H. Hotelling (Eds.), Contributions to probability and statistics: Essays in Honor of Harold hotelling (pp. 278-292). Stanford University Press.

Longfield, M. (1840). Banking and currency. Part II. The Dublin University Magazine, 15, 218-233.

McCulloch, J. R. (1831). Historical Sketch of the Bank of England: With an examination of the question as to the prolongation of the exclusive privileges of that establishment. Longman, Rees, Orme, Brown, and Green.

Miron, J. A. (1986). Financial Panics, the seasonality of the nominal interest rate, and the founding of the fed. The American Economic Review, 76, 125-140.

Neal, L., \& Weidenmier, M. D. (2003). Crises in the global economy from tulips to today: Contagion and consequences. NBER volume globalization in historical perspective.

Neldner, M. (1996a). Bankenfreiheit und Noten-Überemission. McCulloch, Longfield, der Schweizer Franken und die "Small Note Mania" in Schottland. Swiss Journal of Economics and Statistics, 132, 177-195.

Neldner, M. (1996b). Schweizerische Notenbanken im 19. Jahrhundert und Free Banking: Eine Erwiderung. Swiss Journal of Economics and Statistics, 132, 203-206.

Neldner, M. (2003). Competition necessarily tends to produce excess: The experience of free banking in Switzerland. German Economic Review, 4, 389-408.

Nüscheler, H. E. (1912). Die Zürcher Kantonalbank 1870-1904. Verlag E. Speidel. Paillard, G. (1909). La Suisse et L'Union Monétaire Latine. Imprimeries Réunies.

Ritzmann, F. (1973). Die Schweizer Banken. Geschichte-Theorie - Statistik. Verlag Paul Haupt.

Ritzmann, F. (1996). Schweizerische Notenbanken im 19. Jahrhundert und Free Banking: Diskussionsbeitrag zu M.NELDNER, Bankenfreiheit und NotenÜberemmission. Swiss Journal of Economics and Statistics, 132, 197-201.

Weber, E. J. (1988). Currency competition in Switzerland, 1826-1850. Kyklos, 41, $459-78$.

Weber, E. J. (1992). Free banking in Switzerland after the liberal revolutions in the nineteenth century. In K. Dowd (Ed.), The Experience of Free Banking. Routledge.

Wolf, J. (1888). Zur Reform des Schweizerischen Notenbankwesens, Eine eidgenössische Giro-Stelle als Lösung. Verlag von Caesar Schmidt.

\section{Publisher's Note}

Springer Nature remains neutral with regard to jurisdictional claims in published maps and institutional affiliations. 